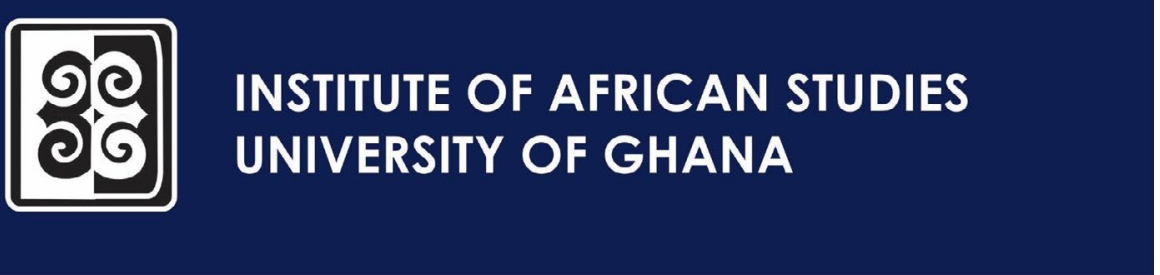

Contemporary Journal of African Studies 2020; 7 (1): 67-83

https://dx.doi.org/10.4314/contjas.v7i1.5

ISSN 2343-6530

(C) 2020 The Author(s)

Open Access article distributed under the terms of the

Creative Commons License [CC BY-NC-ND 4.0]

http://creativecommons.org/licenses/by-nc-nd/4.0

\title{
Reflections on the issue of repatriation of looted and illegally acquired African cultural objects in Western museums
}

\section{Emery Patrick Effiboley}

Head of Department, Department of History and Archaeology, University of AbomeyCalavi

Author email: emery.effiboley@flash.uac.bj

\begin{abstract}
This paper addresses the issue of repatriation/restitution of African cultural objects in Western museums by analysing the terminology used to discuss the demands of return by African states and people. After analysing these used terms which differ slightly from one another, the paper overviews the various types of cultural objects that ended up in European museums. The chapter finally discusses the destinations of the reclaimed cultural objects in postcolonial Africa by showing that not only the original contexts of these cultural objects have changed, but also that the countries asking for the return of these objects should work toward cohering identities for the benefit of all.
\end{abstract}

Keywords: Terminology of heritage circulation, African cultural objects, AfroEuropean relations 


\title{
Reflections on the issue of repatriation of looted and illegally acquired African cultural objects in Western museums
}

\author{
Emery Patrick Effiboley
}

\begin{abstract}
This paper addresses the issue of repatriation/restitution of African cultural objects in Western museums by analysing the terminology used to discuss the demands of return by African states and people. After analysing these used terms which differ slightly from one another, the paper overviews the various types of cultural objects that ended up in European museums. The chapter finally discusses the destinations of the reclaimed cultural objects in postcolonial Africa by showing that not only the original contexts of these cultural objects have changed, but also that the countries asking for the return of these objects should work toward cohering identities for the benefit of all.
\end{abstract}

Key words: Terminology of heritage circulation, African cultural objects, AfroEuropean relations

\section{Résumé}

Cet article s' intéresse à la question du rapatriement et de la restitution des biens culturels africains dans les musées occidentaux en analysant les différents termes utilisés pour discuter des réclamations du retour desdits biens par les Etats et peuples africains. Après un examen de chacun de ces termes qui sont légèrement différents les uns des autres, I' article présente un aperçu général des différents types d 'objets culturels africains retrouvés dans les musées européens. Il se termine par une discussion autour des destinations des biens culturels réclamés dans I 'Afrique postcoloniale en montrant que non seulement le contexte original de ces objets culturels

\section{https://dx.doi.org/10.4314/contjas.v7i1.5}

Dr. Emery Patrick Effiboley (emery.effiboley@flash.uac.bj) is Museologist and Art Historian, and currently Head of Department of History and Archaeology, at the University of Abomey-Calavi (Republic of Benin). He was Andrew W. Mellon Postdoctoral Research Fellow at the Centre for the Creative Arts of Africa at the University of Witwatersrand in South Africa between 2014 and 2016. Dr Effiboley has authored several articles and book chapters in French and English among which the most recent one are "'Les musées africains de la fin du XIXe siècle à nos jours: des apparats de la modernité occidentale' ', Afrika Zamani, Journal of African History (2016); 'Interrogating Museum Development in Africa: From Museum Cooperation to the Appropriation of Praxis', in Thomas Laely, Marc Meyer \& Raphael Schwere, 2018, Museum Cooperation between Africa and Europe. A New Field for Museum Studies, Bielefeld-Kampala, Trancript-Fontain Publications; "Nation Building in Contemporary Benin Republic: The Role of Art, Museums, and Cultural Heritage, in Dimitri M. Bondarenko \& Marina L. Butovskaya, ed., 2019, The Omnipresent Past. Historical Anthropology of Africa and African Diaspora, Moscow, LRC Publishing House. 
n'est plus le même mais aussi que les pays africains réclamant le retour desdits biens culturels devraient prendre les dispositions nécessaires pour que ceux-ci aident à cohérer les identités pour le bénéfice de tous.

Mots-clés: Terminologie de la circulation du patrimoine culturel, objets culturels africains, relations afro-européennes

\section{Introduction}

This paper which speaks from the side of the victims of Western modernity ${ }^{1}$, reflects on the vocabulary of movements of African cultural heritage from its origins to its current destinations around the world. It analyzes the typology of African heritage in Western museums, with a particular reference to cultural objects from the Republic of Benin, in order to open-up new ways in dealing with the repatriation/ restitution/return of cultural heritage of the continent.

\section{Lexicography of Heritage Circulation}

When dealing with the issue of the removal of cultural heritage from Africa to Europe and beyond, there is a set of vocabulary that is used. This said vocabulary comprises words that have slightly different meanings though they are used to express the same phenomena. The words include among others, repatriation, restitution, return, heritage sharing, circulation, etc.

The most meaningful of these words in regards to the issue at hand, in my opinion, is the term repatriation. In its origin repatriation refers to the idea of homeland or patrie and Heimat respectively in English, French and German. Repatriating an object means returning the object to its place of origin, the place where it physically resonates. It is like reweaving a removed part to its original entirety in order to complete meanings. An example is the return of the throne of King Gbehanzin from the Musée du quai Branly (France) to the Benin Republic or, more precisely, to the original territory or community to which the regalia belongs. The idea of repatriation also applies to the return of the Benin bronzes, part of British war booty, from Western museums to the original owners in the former kingdom of Bini in Nigeria. For example, when the throne of Gbèhanzin was loaned and exhibited in December 2006 for a temporary show in Cotonou (Benin) during the

\footnotetext{
${ }^{1}$ I use the words Western modernity because, in the long run of history, there have been more than the European one. The latter is the period succeeding the middle age and starting from the voyage of Christopher Colombus to the Americas through the French revolution in 1789. But what can be called African modernity is the time frame during which African empires such as Ghana, Mali, Monomotapa, Songhay, etc. had thrived while Europe was mainly in its medieval period. And according to the works of scholars like Ivan van Sertima (2003), Pathe Diagne (1992), etc., prior to European landfall, there were several voyages from Africa to what was named America after the traveller, Amerigo Vespucci. So to say, the rise of Europe resulted in the decline of African states. The battle of Ambuila that put an end to the great Kongo empire in 1661 is an example of the fall of Africa into a century-long "darkness".
} 
commemoration of the centenary of the death of the sovereign, one could observe the reverence with which heirs of the kings treated the regalia. They bowed at the objects as if the king had come back, a kind of reconnection to a missing part of their own selves. In essence the word repatriation refers specifically to the cultural identity of the people to whom the object belongs, in the sense that everywhere one sees the object, one thinks of these people, the intrinsic owners, contrary to the 'historical' owners; in this case, European countries who during the past four hundred years removed African cultural objects and heritage from their places of origin (Effiboley, 2004: 110).

The term "restitution" is more frequently used. It also means the return of an illegitimate removal to the owner but, more importantly, implies a (legal) prejudice of repair by the remover. So when one uses the term restitution, one primarily implies consciously or unconsciously the moral dimension of the removal that eventually will require reparation. Concerning the word "return", it simply acknowledges the fact that an object was removed and is returned to its original place. It does not connote an idea of identity or the illegality of the removal. In a way, it is a neutral term and its usage can result in the accusation of erasing the memory of the object or part of its biography. Two other words fall into what I term as lexicography of heritage circulation and which are not far from one another.

The first word or group of words is "heritage sharing" that may mean that people from different part of the world share the enjoyment of a given heritage. Concretely put, it means, for instance, that a cultural object or artwork from Europe can be showed and seen in Africa and everywhere else or an item from Africa can be exhibited at any given place in the world. This idea of sharing was already used during the conference by museums experts and scholars from Asia and Europe in 2002 in Leiden, The Netherlands. According to the editors of the volume published from the conference proceedings, the objective of the conference "was to bring together museum professionals from Asia and Europe to foster co-operation in all areas of activity regarding Asia's cultural heritage" (Fermont and Scott, 2002) but not European heritage.

However, the 2002 conference coincided with the issuing of the "Declaration of Universal Museums' ' signed by 19 museums from the West ${ }^{2}$. The declaration, according to the signatories, entitles the museums with a universal mission and asserted that:

\footnotetext{
2 The declaration was signed by the following museums, The Art Institute of Chicago; Bavarian State Museum, Munich (Alte Pinakothek, Neue Pinakothek); State Museums, Berlin; Cleveland Museum of Art; J. Paul Getty Museum, Los Angeles; Solomon R. Guggenheim, New York; Los Angeles County Museum of Art; Louvre Museum, Paris; Metropolitan Museum of Art, New York; the Museum of Fine Arts, Boston; Museum of Modern Art, New York; Opificio delle Pietre Dure, Florence; Philadelphia Museum of Art; Prado Museum, Madrid; Rijksmuseum, Amsterdam; State Hermitage Museum, St Petersburg; Thyssen-Bornemisza Museum, Madrid; Whitney Museum of American Art; The British Museum (www.thebritishmuseum.ac.uk/newsroom/current2003/universalmuseums.html).
} 
Calls to repatriate objects that have belonged to museum collections for many years have become an important issue for museums. Although each case has to be judged individually, we should acknowledge that museums serve not just the citizens of one nation but the people of every nation (Anonym, 2004: 4).

Others thought that the declaration was a strategy to counter the claims of repatriation that were on the table, and had been for many years and decades, especially the demand of repatriation of Benin bronzes by the Federal Republic of Nigeria. George Abungu, former director general of the National Museums of Kenya, argued as follows:

It seems to me that the declaration on the importance and value of Universal Museums signed principally by a group of large museums who want to create a different pedigree of museum, largely due to fears that materials held in their collections of which the ownership is contested, will face claims for repatriation. It is a way of refusing to engage in dialogue around the issue of repatriation. If the signatories of the Declaration are trying to create the idea that their collections are held in a trust for all of humanity, then why do they still call themselves by their original names? Why not "Universal Museum in Britain" rather than "British Museum" 3 ? (Abungu, 2004: 4).

Following the failure of the strategy to discourage the demand for repatriation and/or restitution, a new term has been coined in the rhetoric about non-western cultural heritage, namely, circulation of cultural heritage. This word "circulation" also has its own connotation or vice.

The word circulation refers mainly to the traffic on the road, of goods, human beings, etc. In both cases, there is someone who initiates the movement of the given object. Applying the word circulation to the issue of movement of (looted and illegally) re-moved cultural heritage, raises various questions. Who has the power to launch the circulation? What is the content of the circulation? Is it intended to have European artworks in circulation? Do we imagine that the Joconda of Leornado da Vinci, The Night Watch of Rembrandt or Les Demoiselles d'Avignon of Pablo Picasso could be part of the content of heritage circulation or only looted and illegally acquired non-western heritage would be?

An important remark on the preference in using one or another of these words is that the term repatriation connotes identities and nations at a moment where national sovereignty is gradually eroded and forgotten in favor of regional ensembles

\footnotetext{
${ }^{3}$ We can see that thereafter some museums in Europe have complied with Abungu's suggestion: The National Museum of Ethnology in Leiden changed its name to Wereldculturen Museum (Museum of World Cultures) while the __ has been re-fashioned Museum für Völkerkunde Wien into Weltmuseum Wien (World Museum of Vienna).
} 
or powers. While restitution is commonly used, the moral dimension involved in it requires a change of paradigm in the legislation of countries. This is the reason why, when addressing the question, the authors of the report commissioned by the French President Emmanuel Macron, Benedict Savoy and Felwine Sarr came up with the term "restitutabilité juridique" (2018: 46). Unless the change has occurred, no restitution is possible except on political grounds. However by identifying this reality, they have omitted another aspect that I call restitutabilité physique (physical restitutability; Effiboley, 2018) in order to express the cultural genocides committed by European Christian missionaries in the Kingdom of Kongo in the $16^{\text {th }}$ century (Balandier, 1968, Anne Hilton, 1985) and later, on a larger scale, in other parts of Africa and the world.

\section{Typology of Benin and Non-Western Cultural Objects in European Museums}

For the past four centuries African cultural objects have been moving to Europe and housed in royal houses, cabinets of curiosity and different museums. One can assume that these African objects do not have the same status or the same degree of legality or illegality. This precaution is necessary due to the evolving nature of the relations between the African continent and Europe. Yahaya Diaby (2017), addressing the subject of the nature of these relations, distinguishes three time frames that include the time of homonymy, the time of antinomy and the time of synonymy. African regions experienced these times in different historical moments. The time of homonymy refers to the egalitarian relationships between Africa and Europe. This was the time when the African kingdoms were sovereign and could decide on their foreign policy as well as on their economic partners. It was for example during that timeframe that King Kpayizonou of Allada (Adres) in the current Republic of Benin sent an ambassador, Matteo don Lopes, to King Louis XIV of France to see with his own eyes if France as a country could be deemed a suitable commercial partner. The trip was made in the context of the war between Portugal, the main actor in the West African coast in $17^{\text {th }}$ century, and the Dutch. The visit itself took place in the Palais de Tuileries in Paris on the $19^{\text {th }}$ December 1670 (D’Elbée, 1671).

This sovereign decision to send an emissary to a country abroad was not something unusual as most African kingdoms were in the position to take such policy actions. Although records of these historical episodes were hidden or deleted in Europe over time, this glorious part of African history is getting slowly unearthed and known publically. As a matter of proof, works like those of Monika Firla (2004), Dieudonné Gnammankou and Yao Modzinou (2008), etc. testify to the historicity of the presence of Africans in the top social hierarchy of European society 4 .

\footnotetext{
${ }^{4}$ During a presentation at the conference, Quels musées pour la mémoire et l'histoire, organised by the French Embassy in Cotonou (Benin) and Université d'Abomey-Calavi, on the 6th december 2018, Antonio de Almeida Mendes, in a paper entitled, 'La mémoire de l'esclavage au Portugal" explained
} 
During this glorious historical moment, gifts were offered to European kings and as records indicate, the Musée du quai Branly holds some of these objects in its collections. The objects offered by Don Matteo Lopes, the emissary of the kingdom of Allada to Louis XIV as gifts were (first) housed in the Musée d'Archéologie in St Germain-en-Laye before being moved successively to Musée du Trocadero and Musée de I' Homme. Given the fact that there have been several African emissaries to European royal courts, it is likely that these kinds of emblematic objects could exist in other countries like Portugal, Italy, Spain, The Netherlands, and Germany.

The American historian, Peter Mark, conducted a lengthy study of the ivory objects by African artists and commissioned by Portuguese in the early modern period (Mark, 2014). An example of these ivory pieces was brought to Holland ${ }^{5}$ in 1727 and because of its uniqueness, was classified and deposited in the Rijksmuseum as a Dutch national treasure until 1950 when it was discovered that the object was brought to the country by a traveler to the former Dutch Gold Coast in West Africa (Effiboley, 2004: 44). The objects that came to Europe and entered the (royal) cabinets of curiosities and later were transferred to museums might probably not be subject to repatriation or restitution because their removal took place at the time of homonymy. Besides, although later in history, there is also another category of objects that were brought to Europe not in a war-related context but in the circumstances preceding colonial conquests. Objects that fall into this sub-category are for instance the gifts offered by King Glèlè (1858-1889) from Danxome ${ }^{6}$ (West Africa) to Wilhelm II of Prussia ${ }^{7}$.

In the geopolitical context after the Conference of Berlin (1884-1885) when European powers started sending organized colonial missions to Africa, the French entered the kingdom of Danxome. However, the King of Agbome, expecting to overcome the threats of the French, tried to strengthen his relationships with the Germans hoping that they would help him defend his kingdom against the French army. The King of Agbome was not aware that, whatever happened, he was already in the colonial trap and that either the French or the Germans would put an end to his power. It is in the context of this poisoned friendship that Glele offered a

how the memories of Africans were deleted both in society and public discourse in Portugal. One can assume that the erasure of African memories in Europe was a common practice and that there is a need to rewrite or reassess the history of Africans in Europe.

${ }^{5}$ It is worth mentioning that Holland was an autonomous province before being integrated by the end of 19 th century into the contemporary country named The Netherlands.

6 Danxome is the indigenous name of the West African kingdom that was conquered by the French army after the wars of 1892 and 1893. After the conquest of the neighboring political entities, the colony of Dahomey is found by the decree of June 221894 . So when I use the first term, it means that I refer to the precolonial kingdom but if the second, the latter refers to the period from the inception of the colony in 1894 to 1975 when the colony has changed its name, becoming Benin.

7 Prussia is the former name of the territory of germanity that goes beyond the contemporary Germany. It includes Austria and parts of Switzerland and Poland. In the latter country that today is not viewed as having been involved in colonialism, there are objects from the kingdom of Danxome. This means that the issue of repatriation/restitution should not be addressed only with known countries with colonial history. 
miniature of his throne to Wilhelm II as well as other objects. Oloukpona-Yinnon (1996) in his book on the relations between Prussia and Danxome publicized these intriguing gifts.

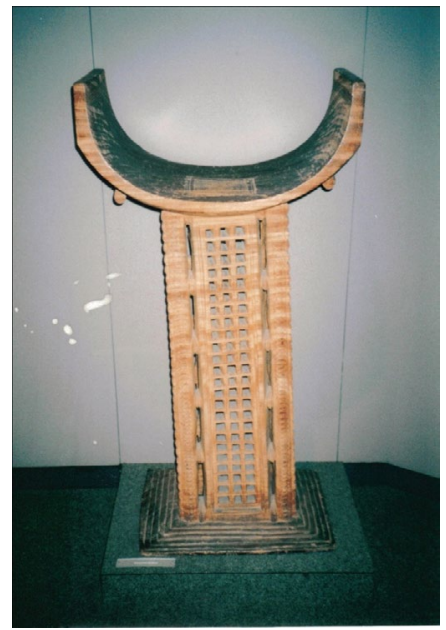

Royal Stool offered to Wilhelm II by

King Glele and housed in Dahlem

Museum, Berlin

(Photo: The author, 2004)

During a study trip from Amsterdam to Berlin, I visited the Dahlem Museum and found them in the permanent exhibition. I immediately recognized the pieces from Agbome and memorized them. Given the fact that Germany didn' $t$ have formal colonial relations with this part of the current Republic of Benin ${ }^{8}$, I started questioning how such materials ended up in the Museum. Applying the theory of gift by Marcel Mauss (Mauss, 1923-1924) - which distinguishes the gift, the counter-gift, and the return of gift - to these cultural objects, one can interrogate the status of these objects from the kingdom of Danxome. Given the fact that the king presumably awaited a counter-gift or return of gift in terms of military support against the French army and that he didn't receive it, one wonders if these materials can still be considered as a gift and be kept as German treasure, or whether they can be subject to repatriation. I hope that the current transformation of the Dahlem Museum into the Humboldt Forum slated to open in the near future will also highlight this episode of German-Danxome diplomatic relations.

The second category of objects from Africa that are subject to claim of repatriation or restitution are those that had been brought to Europe during the time African cultures were vilified and the continent evangelized and colonised. A press campaign justified the war against the Kingdom of Danxome and that eventually drew to an end in $1892^{9}$. In line with the latter, the palace of Agbome, the capital-city of the Kingdom was sacked and the regalia looted and brought to

\footnotetext{
${ }^{8}$ It is useful to complement this idea on German colonialism because there had been attempts of colonialism in the Northern part of Benin Republic. The grave of Mr. Wolf buried in Kandi is a visible proof of this German presence.

${ }^{9}$ Veronique Campion-Vincent dedicated a study to this historical episode in her article entitled, "L'image du Dahomey dans la presse française (1890-1895): les sacrifices humains", 1967, pp. 27-58.
} 
Paris. This act of terrorism helped Colonel Amedee Dodds, the commander of the French army, to receive the title of General in recognition of his achievements. Similar looting was performed by the British army both in Benin City and Ashanti (in modern day Nigeria and Ghana respectively) or in other parts of the continent. Besides, there are many objects in missionary museums in Lyon (France), Berg en Dal and Cadier en Kier (The Netherlands), Roma (Vatican), Lisbon (Portugal) etc. that the missionaries collected after forcing the local people to abandon their indigenous religions. Apart from all these, and prior to the massive exportation of African cultural objects, there are the numerous objects that were burned during the first missionary campaigns in the early modern time across the continent. Several travelers, anthropologists and historians described the cultural crimes committed against the continent. Robert Cornevin, a renowned French colonial administrator and later historian wrote: "The evangelization of the Kongo was going on; churches were built; about two thousands of peoples were baptized per day. Fetishes were also burnt." (Author's translation of Cornevin, 1963: 34; emphasis mine). This burning of religious objects was the key part of the memory erasure committed against Africa.

More recently, Anne Hilton expressed the same drama as follows:

Afonso's first task was to establish the Christian cult in Mbanza Kongo as the established cult of the nkadi mpemba dimension and the royal graves. To do this, he had to destroy the great 'house of nkisi-fetishes' in MbanzaKongo which contained the protective fetishes of the 'old' nkadi mpemba type. (Hilton, 1985: 62).

Given the huge amount of cultural productions burnt at that time, one can also argue that these are materials that cannot be repatriated or restituted since they are gone forever. This is what inspired me to provide a presentation to an earlier museum conversation workshop in Kinshasa in October 2018, "( $L$ ' impossible) restitution des biens culturels : genèse, restituabilité et enjeux". The burning of all these objects belongs to the time of antinomy, according to Yahaya's characterization of Euro-African relations.

The third category of African cultural objects of concern is those objects exported during the time of formal colonial rule. Under the so-called scientific missions, a large part of African heritage was removed. There was the French Dakar-Djibouti mission under the leadership of Marcel Griaule that accumulated several thousand objects from a large part of the continent and deposited these mainly in the then Musée du Trocadero in Paris ${ }^{10}$. It is also worth mentioning the German missions of Leo Frobenius in Africa, Nigeria being a cardinal point in those missions. These objects were removed from Africa neither with the consenting will of local people nor their agreement.

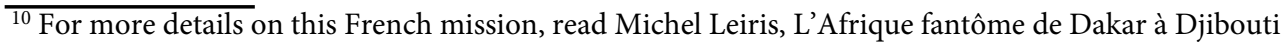
(1931-1933) published at Gallimard in Paris.
} 


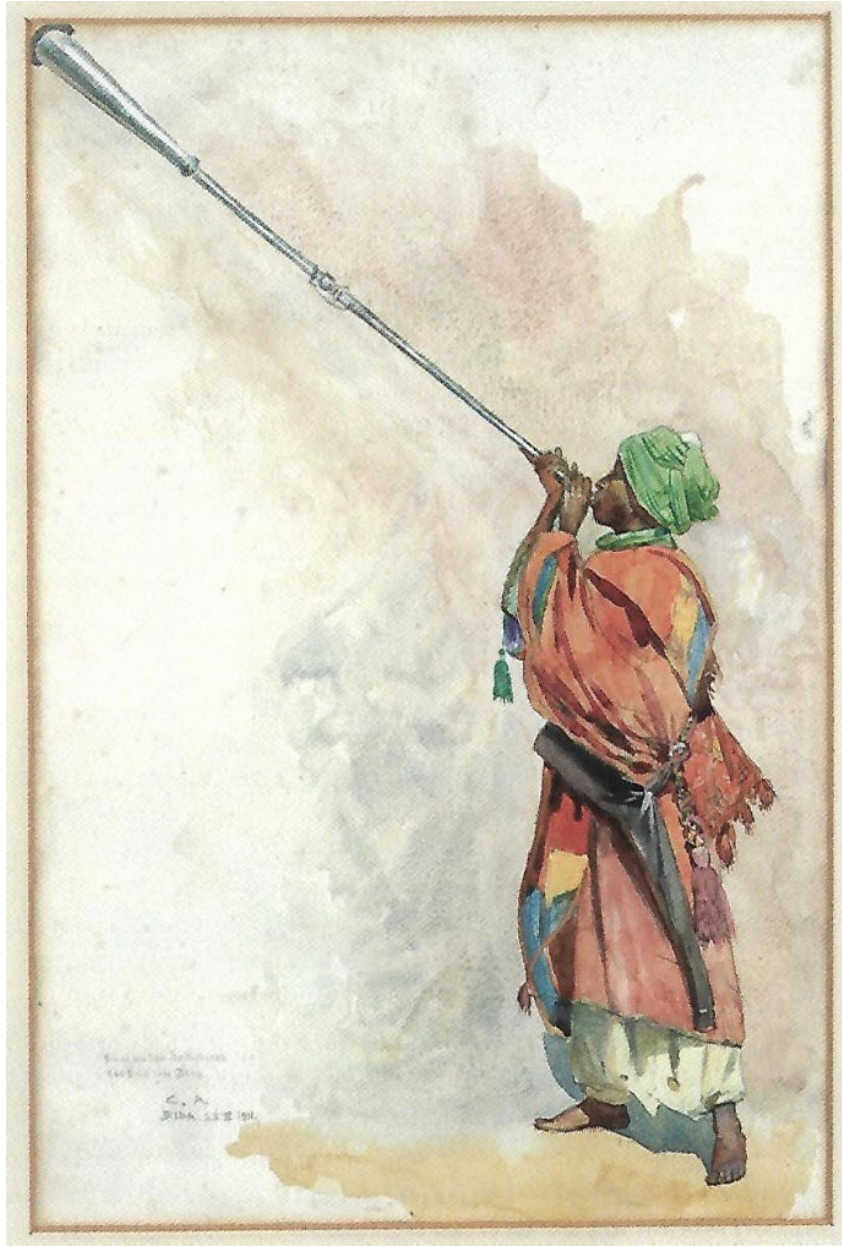

Player of kankatshi at the royal court of Bida (Kuba and Hambolu, 2010)

\section{Dealing with Historical Cultural Objects}

The above overview of the main categories of objects in European museums has laid the foundation for discussing how these materials kept out of the reach of the intrinsic owners must be dealt with (Effiboley, 2004: 110). The following analysis first focuses on the war-related materials followed by the religious-cultural objects and eventually the issue of sharing cultural heritage from the perspective of the victims of the looting in Africa.

The issue of historical cultural objects is a sensitive one, especially when it is linked to war-related materials. A large part of Western museums' owned collections belong to this category. In fact, these objects are those looted during colonial conquests in Africa and elsewhere in the world. The case of the kingdom of Danxome of which the centre is in the contemporary Republic of Benin, is a good example. After the colonial war of 1891-1892 and the surrender of King 
Gbehanzin, the most symbolic regalia were looted and exported by Colonel Amedee Dodds and his acolytes. This category of objects, which I regard as war or bloodrelated objects, should be returned to the intrinsic owners without condition. The reason for this is that these exiled objects belong to a set of objects that has been dismantled by the colonizers. Repatriating them is not only returning them to their home but also completing/re-appropriating the meaning or their original meaning to the benefit of future generations both at home and abroad.

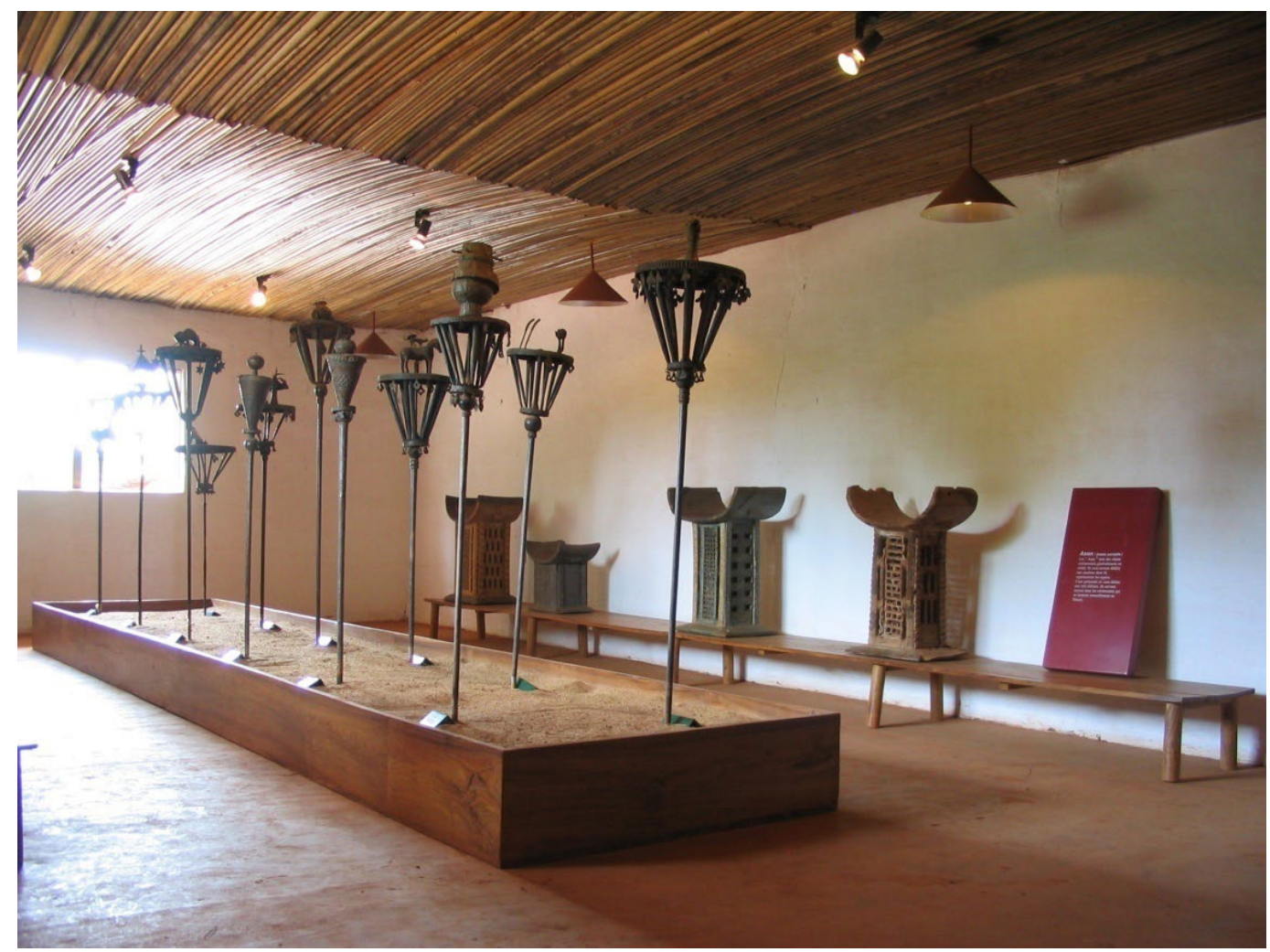

View of the gallery in the Historic Museum in Abomey, (Photo: Franck Houndegla, 1998)

Analysing the thrones behind the back of the iron altars in the photograph above relating to the thrones attributed to Glele (1858-1889) or Gbehanzin (18891892) illustrates this. Why, for example, are some of the thrones of a smaller size than the other which is almost about two meters high? Does it say something about the kingdom of Danxome itself or of the power of each of the kings? 


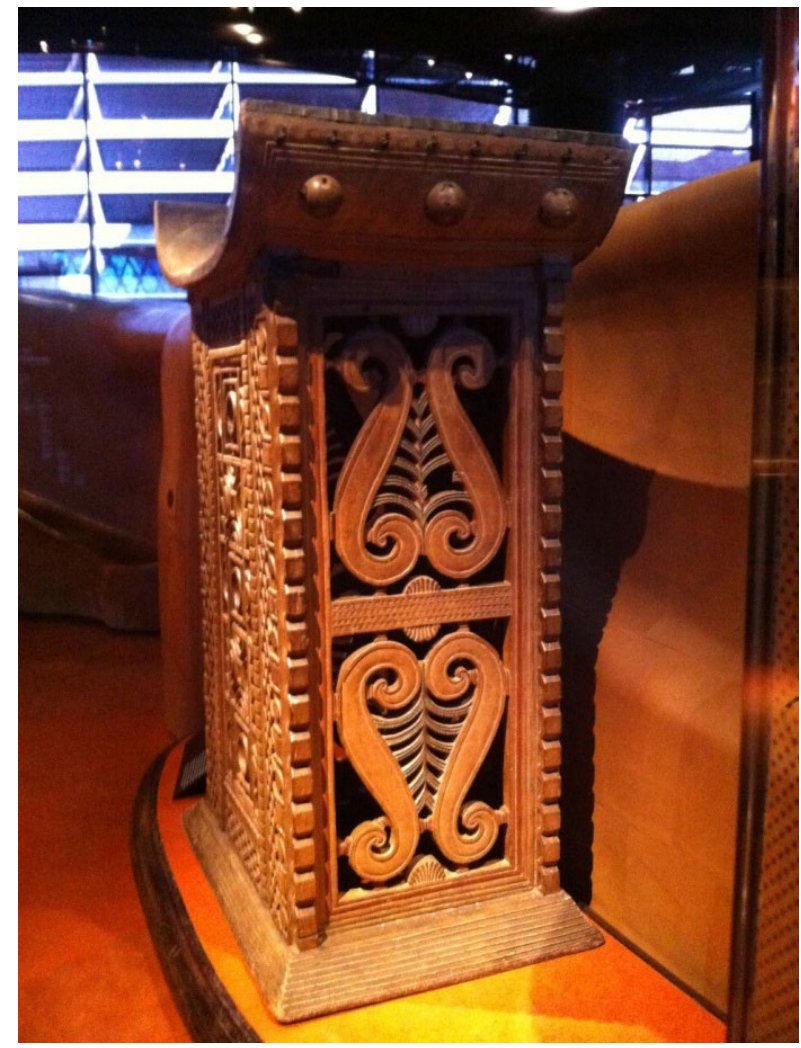

View of the gallery in Musée du quai Branly in Paris, (Photo : The author, 2017)

A similar analysis may be applied to the Benin bronzes that originated from the Kingdom of Bini in the contemporary Federal Republic of Nigeria. It is of public notoriety that the bronzes left Africa only after the sacking of the kingdom by the British Army in 1897. As indicated (Effiboley, 2004), the German version of the Museum of World Cultures in Vienna website mentioned that the looting by the British was the thrust of the spreading of these materials. In order to show the continuity in the creativity of the artists in the home of these bronzes, the exhibition, Benin Kings and Rituals: Court Arts from Nigeria, curated by Barbara Plankensteiner in 2007, presented not only the historical bronzes gathered from all the Western museums but also collections from Nigeria as well as contemporary creations. This juxtaposition showed how the heirs of this tradition are still attached to the historical pieces. Unfortunately, when the same exhibition was presented in the Musée du quai Branly in 2008 with the title, Bénin: cinq siècles $d$ 'art royal, the contemporary part was cut off. ${ }^{11}$ This is a vicious strategy to induce discontinuity of artistic creation while the heirs care very much about their heritage.

${ }^{11}$ Another hidden aspect in the French version of the same exhibition is that the title creates and sustains a confusion in the mind of French audience about the kingdom of Bini or Bini City and Benin Republic. 
The above-indicated categories of cultural objects are however not supposed to have the same treatment given the circumstances of their removal from their place of origin.

In my opinion, the war/blood related objects should be repatriated without any discussion. Several of the museum collections in the West fall in that framework. The most symbolic objects from the kingdom of Danxome are housed in the Musée du quai Branly and are supposedly the ones that the French president, Emmanuel Macron has decided on the $29^{\text {th }}$ November 2018 to repatriate to the Republic of Benin.

There is a second category of objects that require repatriation and these include religious objects linked with cults which are still active. In the parts of Africa where such religious practices are current, their ritual objects have to be repatriated. Repatriation to this end has occurred between The Netherlands and Indonesia. In fact, after long negotiations, in 1976 the Dutch government repatriated ritual objects from the Lombok temples in the Singarasi to the Indonesian government and the objects were relocated to their original place where they have continued to be used for religious purposes (Effiboley, 2004). There is an emblematic artwork from the kingdom of Danxome that falls in this category. It is the two meterhigh sculpture of $\mathrm{Gu}$, the god of iron and hunting which plays a pivotal role in the pantheon of Adja-fon and Yoruba peoples in West Africa (Effiboley, 2019: 156).

The reason given as to lack of repatriation of this category of cultural objects is that in some areas in Africa, the christianization has erased religious memories so deep that the heirs of the owners and makers of these religious objects no longer recognize themselves in them. Eugenia Shanklin (1990: 62-69) has narrated a case in present-day Cameroon where the community has refused to receive the repatriated objects. In such cases, the government of the country to which the community belongs has the responsibility to receive the objects and house them in a museum at least for furthering the studies in the material culture of the country.

The last aspect of this discussion deals with the handling of exiled cultural objects within the contemporary context for which UNESCO offers a framework. In fact, in the past few decades, the demand for repatriation and restitution has increased both from African countries and others in the Global South. To counter these demands, the museums in the countries of what is unilaterally named the Global North have come up with the concepts of circulation and sharing. The rhetoric behind these concepts is to say, as the above-quoted declaration stated, that the museum is in the service of every nation. As such, the fact that an object is in place $A$ or $B$ is not what matters unless it serves the whole humanity.

The weak point in this argument is that the concepts of circulation and sharing create a kind of double standard. They assume that non-European cultural objects 
and artworks need to be circulated and shared among the whole humanity. But no provision is made for the circulation of European artworks in Africa or, for that matter, in the Global South. It has been more than a decade since I have argued for this idea of making European artworks accessible for audiences in Africa.

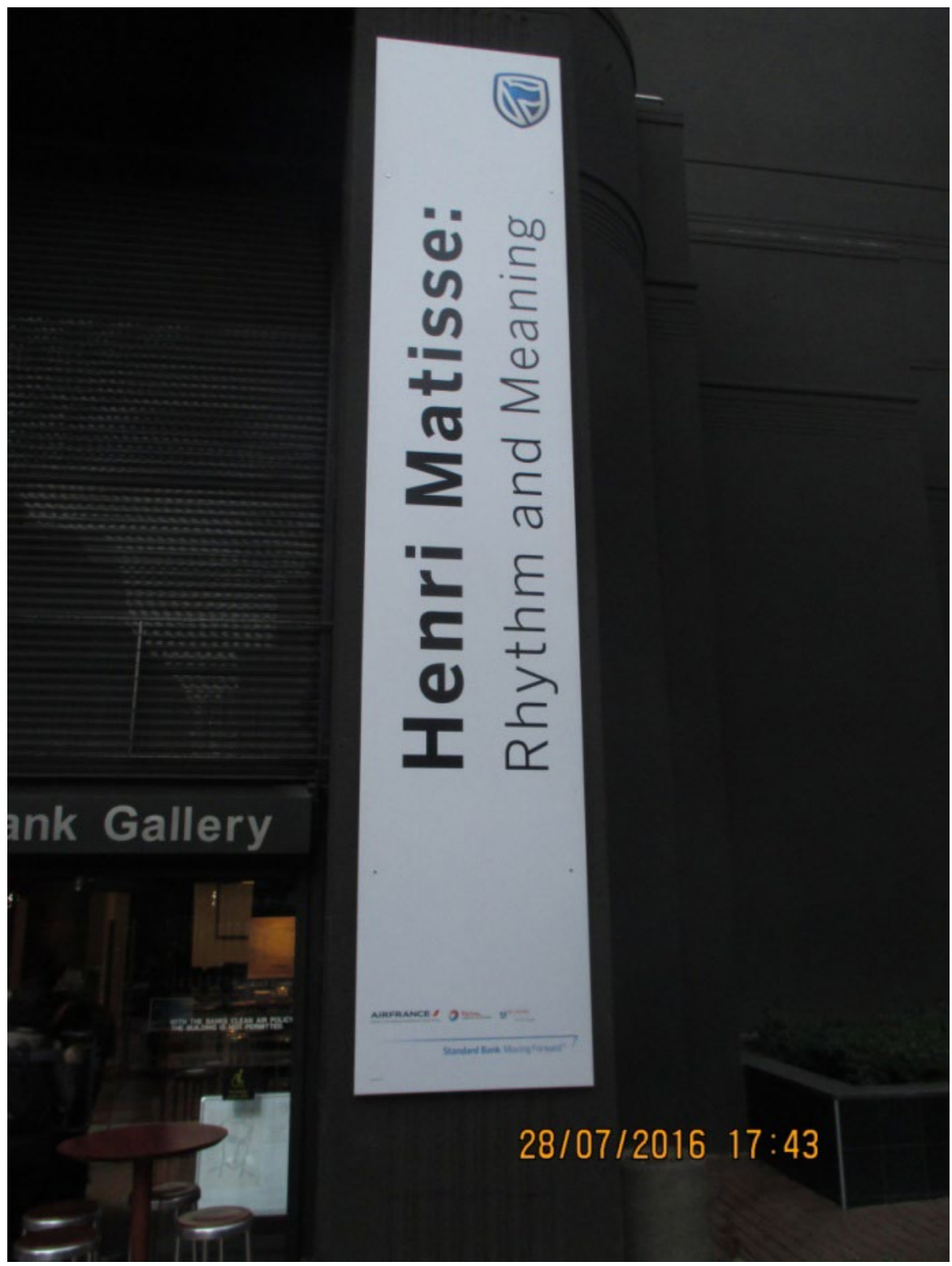

Poster of Matisse's exhibition in Johannesburg

(Photo: The author, July 2016) 
I suggested, for instance, that in coherence with these concepts, artworks like those of famous artists such as Pablo Picasso, Rembrandt, Rubens and others be exhibited in African museums in order to counter-balance this long-standing bias in the field of cultural circulation (Effiboley, 2004). Coincidentally, an exhibition on the Spanish artist, Pablo Picasso was presented in 2006 in South Africa on the theme, Picasso and Africa. Ten years later, in 2016 the Standard Bank Gallery in South Africa hosted another exhibition on Matisse with the title, Henri Matisse: Rhythm and Meaning from July $13^{\text {th }}$ to September $17^{\text {th }}, 2016$.

Apart from South Africa with its heritage of settler colonialism, no other country on the continent has this "privilege" to host such an exhibition. During a public debate ${ }^{12}$ on the theme, Memory and Universality: News Challenging facing Museums, February $7^{\text {th }}, 2007$ I raised this issue and a Frenchman in the audience argued that copies of these artworks would be sent to Africa. As a response to a claim for fairness and justice in the circulation of cultural heritage, this answer was the most insulting for the peoples of the countries of origin given the thousands artworks the West has kept for her single enjoyment. Nevertheless, it is worth mentioning that in the 1960s during the time of President Leopold Sedar Senghor, there were exhibitions of artists like Picasso, Gauguin, etc. in Dakar. But these exhibitions should be analysed in the framework of Senegal being the former capital-city of the (colonial) French West Africa (AOF) and the president being himself a member of the negritude movement. It is in line with the latter that the $1^{\text {st }}$ Festival of Black Artists took place in Dakar with a huge exhibition of African art gathered from most countries of the continent.

Beyond the issues of global object removals, the holistic question is how we re-imagine the relations between Africa and Europe, and to some extent the rest of the world. It is about the way African history is written and, more importantly, the way the archives are used. This is why the demand for repatriation and restitution should include access to historical archives produced about Africa and more largely on the Euro-African relations that developed at least from the $15^{\text {th }}$ century.

\footnotetext{
${ }^{12}$ Among the participants of the debate were Gary Edson, member of the Executive Committee of the International Council of Museums (ICOM), Museum ethics specialist and professor and Director of the museum studies programme at Texas tech University/Museum, Jack Lohman, Director of the British Museum, and the directors of Musée du Louvre (France), the State Hermitage Museum of St Petersburg (Russia), etc.
} 


\section{Conclusion}

After this reflection on African cultural objects removed from their original contexts, it is clear that their histories are far more complex than the issues of repatriation/restitution for which African states are vehemently demanding and which the West is denying equally strongly. It is about the structural relations established by Western countries since the early years of European modernity and to their single and exclusive advantage. Discussing the fate of these exiled objects and artworks is about re-balancing the relationships between the West and the African continent in terms of knowledge production, economic development, and much more. But this change cannot occur without the active participation of Africans themselves. Only this participation will help to change the (negative) rhetoric about the continent. 


\section{References}

Abungu, G. (2004). The declaration: A contested issue, in ICOM News 1 (4).

Abungu, G. (2008). Universal Museums: New Contestations, new controversies. In Gabriel M. and Dahl J. (Eds.), UTIMUT. Past Heritage - Future Partnerships. IWGIA/NKA, Copenhagen.

Almeida, M. A. (2018) La mémoire de l' esclavage au Portugal, paper presented at the conference, Quelsmusées pour la mémoire et l'histoire, organised by the French Embassy in Cotonou in collaboration with Universitéd AbomeyCalavi on 6th December 2018.

Anonym, (2004) Declaration of the Importance and Value of Universal Museum, ICOM News 1 (4).

Balandier, G. (1968) Daily life in the kingdom of the Kongo. From the Sixteenth to the Eighteenth Century. London: George Allen and Unwin Ltd.

Campion-Vincent, V. (1967). L' image du Dahomey dans la presse française (18901895) : les sacrifices humains. Cahiers d'études africaines, 7 (25) 27-58.

D'Elbée, (1670). Côte d'or. Sa découverte. Etablissement des Européens. In Chevalier Des Marchais, Histoire générale des voyages depuis le commencement $d u X V^{e}$ siècle. Première partie. www.gallica.bnf.fr

Diagne, P. (1992). Bakari II, 1312, Christophe Colomb, 1492, à la rencontre de l'Amérique, Bruxelles: Sankoré.

Effert, R. (2003). Volkenkundigverzamelen. Het Koninklijk Kabinet van Zeldzaamheden en het Rijks Ethnographisch Museum (1816-1883), PhD Thesis, University of Leiden.

Effiboley, E. P. (2004). Acquisition and Access of an African Collection in a European Museum to Audiences in Africa: Case Study of the National Museum of Ethnology in Leiden, The Netherlands, Master Thesis in Museology, Amsterdam School of the Arts.

Effiboley, E. P. (2018). (L'impossible) restitution des biens culturels: genèse, restituabilité et enjeux, Paper presented at the workshop, Les musées en convers(at)ion. Perspectives congolaises sur la restitution des biens culturels et la transformation des pratiques muséales en Afrique, Institut des Beaux-Arts de Kinshasa, Kinshasa, 21-24 October 2018. 
Effiboley, E. P. (2019). Nation Building in the Contemporary Benin Republic: The Role of Art, Museum and Cultural heritage. In Bondarenko D. and Butovskaya M. (Eds), The Omnipresent Past. Historical Anthropology of Africa and African Diaspora (pp. 151-161). Moscow: LRC Publishing House.

Fermont, W. \& Scott, G, (2002). Asia-Europe Marketplace of Museums. Sharing Cultural Heritage, (Ed). Report on the Asia-Europe Conference on Sharing Cultural Heritage, Leiden, April 2002, National Museum of Ethnology, National Museum of Philippines and International Institute of Asian studies.

Firla, M. (2004). In Search of the Viennese African Angelo Soliman (ca. 172196): From Educator of a Hereditary Prince Stuffed Exhibit' ', TINABANTU, Journal of African National Affairs 2 (1) 75-90.

Gnammakou, D. \& Modzinou, Y. (2008). Les Africains et leurs descendants en Europe avant le 19è siècle, Toulouse :Mat éditions.

Hilton, A. (1985). The Kingdom of Kongo, Oxford: Clarendon Press.

Kuba, R. \& Hambolu, M. (Ed) (2010). Nigeria 100 Years ago through the Eyes of Leo Frobenius and his Expedition team, Francfort, Frobenius Institute at the Goethe University, Frankfurt/Main.

Leiris, M., (1934). L'Afrique fantôme. De Dakar à Djibouti (1931-1933). Paris : Gallimard.

Mark, P. (2014). L' image du global au 16ème siècle : représentation en ivoire du commerce en Afrique de l'ouest, Inaugural lecture presented at the 3rd Rencontres d'études africaines (REAF2014), Université de Bordeaux, June 30th 2014.

Mauss, M. (1923-1924). Essai sur le don. Forme et raison de l' échange dans les sociétés primitives, L’Année sociologique, seconde série, 1923-1924.

Oloukpona-Yinnon, P. (1996). Gbêhanzin und die Deutschen. Der Schriftwechsel zwischen Danhomê und Deutschland von 1882 bis 1892 in deutsch und französich, Berlin: Edition Oost

Savoy, B. and Sarr, F. (2018). Restituer le patrimoine africain. Paris : Philippe Rey.

Sertima, I. (1976). They came before Colombus. The African presence in ancient America, New York: Random House.

Shanklin, E. (1990). The Odyssey of Afo-a-Kom, in African Arts, 23 (4) 62-69.

Yahaya, D. (2018). “ Cultures africaines, information et mondialisation historique." In Communication présentée à l'occasion du FESTICOLL tenu les 26 au 29 avril 2017 à Université Gaston Berger de Saint-Louis au Sénégal (manuscrite). 